\title{
The effects of hydro- and osmopriming on the germination, vigour and hydrolytic enzymes activity of common zinnia (Zinnia elegans Jacq.) seeds
}

\author{
Dorota Szopińska ${ }^{1 *}$, Barbara Politycka ${ }^{2}$ \\ ${ }^{1}$ Department of Plant Pathology, Seed Science and Technology \\ Poznań University of Life Sciences \\ Szamotulska 28, 62-081 Przeźmierowo, Poland \\ ${ }^{2}$ Department of Plant Physiology \\ Poznań University of Life Sciences \\ Wołyńska 35, 60-637 Poznań, Poland
}

\begin{abstract}
Priming is one of the most common methods of improving seed quality. The aim of this experiment was to study the effects of hydro- and osmopriming on the germination, vigour and hydrolytic enzymes $(\alpha$-amylase, $\beta$-glucosidase, exopeptidase and lipases) activity of zinnia (Zinnia elegans Jacq.) seeds. Seeds of three cultivars: Jowita, Kirke and Orys, and Z. elegans fl.pl., a mixture of cultivars (Mix), were tested. The seeds were hydroprimed in a restricted volume of water $\left(200 \mu \mathrm{H}_{2} \mathrm{O} \mathrm{g} \mathrm{g}^{-1} \mathrm{seed}, 24 \mathrm{~h}\right.$ at $\left.15^{\circ} \mathrm{C}\right)$ and osmoprimed in a polyethylene glycol solution (-1.0 MPa PEG 8000, 5 days at $20^{\circ} \mathrm{C}$ ). Untreated seeds served as the control. The cultivars differed significantly in terms of seed quality as well as response to priming. On average, 'Jowita' seeds were characterised by the highest quality, expressed by the total number of germinating seeds $\left(\mathrm{G}_{\max }\right)$ and germination at the $1^{\text {st }}$ and $2^{\text {nd }}$ counts. Mix seeds showed the lowest quality, expressed by germination at the $1^{\text {st }}$ and $2^{\text {nd }}$ counts and vigour. Generally, an increase in $\alpha$-amylase activity and a decrease in lipase activity was found in hydroprimed and osmoprimed seeds, and $\alpha$-amylase activity was significantly higher in 'Jowita' seeds than Mix seeds. The applied treatments did not affect $\beta$-glucosidase and exopeptidase activity in the tested seeds. Osmopriming accelerated seed germination and influenced $\alpha$-amylase and lipase activity to a greater extent than hydropriming. Among the assayed enzymes, only the activity of $\alpha$-amylase may be potentially useful for the seed industry as a physiological marker of zinnia seed vigour and the effectiveness of osmopriming.
\end{abstract}

Key words: $\alpha$-amylase, $\beta$-glucosidase, exopeptidase, lipases, polyethylene glycol

\section{INTRODUCTION}

Priming is one of the most common and universally used methods for improving seed quality. The process permits partial seed hydration so that pregerminative metabolic activity proceeds but germination is prevented. Properly conducted priming causes an increase in germination percentage and germination rate, enables seeds to germinate under a broader range of environmental conditions and improves seedling vigour and growth (McDonald 2000). The positive effects of priming are attributed to the induction of the biochemical mechanisms of cell repair, activation

\footnotetext{
*Corresponding author.

Tel.: +48 618163591 ;

e-mail: dorota.szopinska@up.poznan.pl (D. Szopińska).
} 
of the antioxidant defence system and induction of enzymes catalysing the decomposition and mobilisation of storage compounds (Di Girolamo and Barbanti 2012). Seeds generally contain starch, proteins and triacylglycerols, in proportions depending on the plant species, as sources of matter and energy. During germination, these three major nutrient reserves are hydrolysed specifically by amylases, proteases and lipases, respectively (Barros et al. 2010, Di Girolamo and Barbanti 2012). $\alpha$-Amylase hydrolyses starch into the simple sugar glucose (Kaneko et al. 2002). $\beta$-Glucosidases have been implicated in the degradation of $\beta$-glucans produced by the endo-type $\beta$-glucanases of cell walls (Akiyama et al. 1998). Aminopeptidases participate in the final stages of protein degradation and hydrolyse peptide bonds, yielding amino acids from N-terminal peptides and proteins (Abdala et al. 1999). Lipases catalyse the hydrolysis of longchain triacylglycerols into glycerol and free fatty acids, although their substrates can also be esters of medium- or short-chain fatty acids (Cavalcanti et al. 2007). An increase in $\alpha$-amylase activity in primed seeds has been reported by many authors (Sung and Chang 1993, Lee and Kim 1999, Singh et al. 1999, Lee and Kim 2000, Mukasa et al. 2003, Basra et al. 2005, Sathish and Sundareswaran 2010, Dehghanpour Farashah et al. 2011). However, there are not many reports on the activity of other hydrolytic enzymes after seed priming.

Zinnia (Zinnia elegans Jacq.), cultivated usually on flowerbeds and for cut flowers, belongs to the worldwide most popular group of annual ornamental plants. The results of previous experiments have shown that hydropriming as well as osmopriming may significantly accelerate the germination of zinnia seeds (Szopińska and Tylkowska 2009, Szopińska and Wojtaszek 2011, Szopińska 2011). However, there are no reports about the enzyme activity in these seeds. The activity of some enzymes may be potentially used in the seed industry as physiological markers of seed germination and priming efficacy. Hence, the aim of the conducted study was to determine the effect of two priming techniques, hydro- and osmopriming, on the germination and vigour of zinnia seeds in relation to the activity of hydrolytic enzymes.

\section{MATERIAL AND METHODS}

Four samples of Zinnia elegans Jacq. seeds produced by seed company TORSEED in Torun (Poland) were used in the study: 'Jowita', 'Kirke', 'Orys' and Z. elegans fl.pl., a mixture of cultivars (Mix). The optimal conditions for the hydro- and osmopriming of zinnia seeds were established during a series of preliminary experiments.

\section{Hydropriming}

For hydropriming, seeds were placed in $100 \mathrm{~cm}^{3}$ flasks and $200 \mu \mathrm{l}$ of distilled water per $1 \mathrm{~g}$ of seeds was added. Then the flasks were sealed with parafilm and aluminium foil and incubated in darkness at $15^{\circ} \mathrm{C}$ for $24 \mathrm{~h}$. After the treatment, seeds were dried in semi-open Petri dishes at $20^{\circ} \mathrm{C}$ and $45 \%$ relative humidity for $24 \mathrm{~h}$ to an equilibrium moisture content.

\section{Osmopriming}

For osmopriming, 50 seeds were placed in each 9 $\mathrm{cm} \varnothing$ Petri dish on four layers of blotters moistened with $5 \mathrm{~cm}^{3}$ of polyethylene glycol (PEG 8000, Sigma-Aldrich Co.) solution of osmotic potential of $-1.0 \mathrm{MPa}$ and incubated for five days in darkness at $20^{\circ} \mathrm{C}$. To obtain this solution, $284 \mathrm{~g}$ of PEG was dissolved in 1 litr of sterile water (Michel and Kaufman 1973). The Petri dishes were sealed with parafilm. After priming, the seeds were washed under tap water for $3 \mathrm{~min}$. and rinsed three times in sterile distilled water to remove PEG. Then the seeds were dried with filter paper and next in semiopen Petri dishes at $20^{\circ} \mathrm{C}$ and $45 \%$ relative humidity for $24 \mathrm{~h}$ to an equilibrium moisture content.

\section{Seed germination and vigour}

For the germination test, eight replications of 50 seeds from each treatment were tested. The seeds were placed in $9 \mathrm{~cm} \varnothing$ Petri dishes $(25$ seeds per dish) containing six layers of moistened blotters and incubated in darkness, at $20^{\circ} \mathrm{C}$. Percentages of normal seedlings (germination at the $1^{\text {st }}$ and $2^{\text {nd }}$ count) and abnormal diseased seedlings were calculated after four and 10 days according to ISTA rules (ISTA 2012). Additionally, the total number of germinating seeds $\left(\mathrm{G}_{\max }\right)$ was determined on the base of the vigour test.

To characterise seed vigour, eight replications of 50 seeds were incubated under the same conditions as in the germination test. Radicle protrusion was scored daily for 10 days. The germination rates, characterising seed vigour, i.e.: $\mathrm{T}_{10}$ - time to $10 \%$ of the total number of germinating seeds $\left(\mathrm{G}_{\max }\right)$ and MGT - mean germination time were evaluated using GERMINATOR software (Joosen et al. 2010).

\section{Enzymes assays}

To obtain the embryos for all enzymatic analyses, the seeds were placed in $9 \mathrm{~cm} \varnothing$ Petri dishes on 
four layers of blotters soaked with distilled water and incubated at $20 \pm 2^{\circ} \mathrm{C}$ for $24 \mathrm{~h}$ in darkness. Each enzymatic analysis was repeated four times.

The activity of $\alpha$-amylase (1,4- $\alpha$-D-glucanohydrolase; EC 3.2.1.1) was determined by the Bernfeld (1955) method consisting of measuring the coloured product of the reduction of 3,5-dinitrosalicylic acid by the reducing group of sugars developed due to starch hydrolysis. The $0.1 \mathrm{~g}$ samples of embryos were ground in a cooled mortar with $2.5 \mathrm{~cm}^{3}$ of sodium phosphate buffer of pH 6.9 with sodium chloride in a concentration of $0.6 \mathrm{mM}$. Subsequently, the samples were centrifuged at $15,000 \times g$ for $20 \mathrm{~min}$. and the obtained supernatant was an enzymatic extract. The reaction mixture, containing $0.5 \mathrm{~cm}^{3}$ of enzymatic extract and $0.5 \mathrm{~cm}^{3}$ of $1 \%$ soluble starch solution dissolved in an extraction buffer, was incubated for $3 \mathrm{~min}$. at $25^{\circ} \mathrm{C}$. Then, $1 \mathrm{~cm}^{3}$ of 3,5-dinitrosalicylic acid was added and the samples were heated for $5 \mathrm{~min}$. in a boiling water bath to terminate enzymatic reaction. After cooling down, $5 \mathrm{~cm}^{3}$ of distilled water was added to the samples. Absorbance was measured spectrophotometrically at a wavelength of $540 \mathrm{~nm}$.

The activity of $\beta$-glucosidase ( $\beta$-D-glucoside glucohydrolase; EC 3.2.1.21) was determined by the method of Nicols et al. (1980). The $0.1 \mathrm{~g}$ of embryos were ground in cooled mortar and extracted with $5 \mathrm{~cm}^{3}$ of $0.1 \mathrm{M}$ potassium phosphate buffer of $\mathrm{pH} 7.0$, containing $0.5 \%$ polyethylene glycol (PEG 6000) and $50 \mathrm{mg}$ of Polyclar AT. The samples were centrifuged at $10,000 \times g$ for $15 \mathrm{~min}$. The reaction mixture containing equal volumes of the 10 -fold dissolved enzyme extract and 4-nitrophenyl- $\beta$-D-glucopyranoside $\left(2 \mathrm{mg} \mathrm{cm}^{-3}\right)$ was incubated for $60 \mathrm{~min}$. at $35^{\circ} \mathrm{C}$. The reaction was terminated by an addition of $0.2 \mathrm{M} \mathrm{Na}_{2} \mathrm{CO}_{3}\left(1.5 \mathrm{ml} \mathrm{cm} \mathrm{cm}^{-3}\right)$. Formed $p$-nitrophenol was determined spectrophotometrically at $400 \mathrm{~nm}$.

The activity of exopeptidase (leucyl aminopeptidase; EC 3.4.11.1) was determined by Worthington's method (1993). The $0.1 \mathrm{~g}$ samples of embryos were ground in a cooled mortar with $10 \mathrm{~cm}^{3}$ of $0.02 \mathrm{M}$ TRIS-maleic buffer of $\mathrm{pH} 6.0$. Then, the samples were centrifuged at $12,000 \times$ $g$ for $40 \mathrm{~min}$. The obtained supernatant was an enzymatic extract. The reaction mixture contained $0.4 \mathrm{~cm}^{3}$ of enzymatic extract, $1 \mathrm{~cm}^{3}$ of $0.02 \mathrm{M}$ TRIS-maleic buffer of $\mathrm{pH} 6.0$ and $1 \mathrm{~cm}^{3}$ of substrate ( $0.6 \%$ L-leucine- $\beta$-naphtylamide hydrochloride). The samples were incubated at $30^{\circ} \mathrm{C}$ for $60 \mathrm{~min}$. and then transferred to a water bath and kept at $70^{\circ} \mathrm{C}$ for $10 \mathrm{~min}$. to stop the enzymatic reaction. After cooling down, the samples were centrifuged at $3,000 \times \mathrm{g}$ for $10 \mathrm{~min}$. and then $5 \mathrm{~cm}^{3}$ of $0.02 \%$ Fast Garnet GBC dye was added to a precipitate of each sample to bind naphthylamine and to obtain a coloured complex. Absorbance was measured spectrophotometrically at a wavelength of $500 \mathrm{~nm}$.

Lipase (triacylglycerol acylhydrolase; EC 3.1.1.3) activity was determined by the method of Achakzai et al. (2003). Acetonic powder was obtained by homogenizing the embryos of zinnia seeds in acetone and separating acetone from the solid part by filtration and evaporation at room temperature (Cavalcanti et al. 2007). Next, $0.1 \mathrm{~g}$ of the powder was extracted with $2 \mathrm{~cm}^{3}$ of $0.05 \mathrm{mM}$ phosphate buffer of $\mathrm{pH} 8.0$ for $45 \mathrm{~min}$. at $26^{\circ} \mathrm{C}$. Subsequently, the extract was centrifuged at $11,000 \times g$ for $30 \mathrm{~min}$. $3.75 \mathrm{~cm}^{3}$ of $48 \%$ ammonium sulphate was added to $1.5 \mathrm{~cm}^{3}$ of supernatant and was placed for $30 \mathrm{~min}$. at $4^{\circ} \mathrm{C}$. Next, samples were centrifuged at $5,000 \times$ $g$ for $30 \mathrm{~min}$., the supernatant was discarded and the precipitate was dissolved in $1.5 \mathrm{~cm}^{3}$ of $0.05 \mathrm{mM}$ phosphate buffer of $\mathrm{pH}$ 8.0. The obtained solution was an enzymatic extract. The reaction mixture contained $0.1 \mathrm{~cm}^{3}$ of enzymatic extract, $2.3 \mathrm{~cm}^{3}$ of $0.1 \mathrm{M}$ TRIS buffer of $\mathrm{pH} 9.0$ and $0.6 \mathrm{~cm}^{3}$ of 4-nitrophenyl laurate (the emulsion was obtained by a solution of $1 \mathrm{~cm}^{3}$ of $20 \mathrm{mM}$ laurate solution in acetone with $8 \mathrm{~cm}^{3}$ of $0.1 \mathrm{M}$ acetate buffer of $\mathrm{pH} 3.8,4 \mathrm{~cm}^{3}$ of $1 \%$ polyvinyl alcohol and was supplemented to $20 \mathrm{~cm}^{3}$ with $0.1 \mathrm{M}$ acetate buffer of $\mathrm{pH}$ 3.8). Samples were incubated for $1 \mathrm{~h}$ at $30^{\circ} \mathrm{C}$. Absorbance was measured spectrophotometrically at a wavelength of $405 \mathrm{~nm}$.

\section{Statistical analysis}

Data related to germination, vigour and enzymes activity were processed by two-way ANOVA (the first factor was the treatment, the second was the cultivar) using STAT software. The significance of differences was evaluated by Duncan's multiple range test at $p=0.05$.

\section{RESULTS}

The examined cultivars differed significantly in terms of seed germination and vigour as well as response to priming (Tabs 1 and 2). Before priming, a very high total number of geminating seeds was observed for 'Jowita' and 'Kirke' (93.8 and 95.8\%, respectively), a lower one for 'Orys' (85.5\%) and the lowest for Mix (74.8\%). After hydro- and osmopriming, a significant decrease in this parameter was observed only for 
Table 1. The effect of hydro- and osmopriming on the germination of zinnia seeds (\%)

\begin{tabular}{|c|c|c|c|c|c|c|}
\hline Item & Treatment & Jowita & Kirke & Orys & Mix & Mean \\
\hline \multirow{4}{*}{$\begin{array}{l}\text { Total number of } \\
\text { germinating seeds } \\
\left(\mathrm{G}_{\max }\right)\end{array}$} & Control & $93.8 \mathrm{de}^{*}$ & $95.8 \mathrm{e}$ & $85.5 \mathrm{bc}$ & $74.8 \mathrm{a}$ & $87.4 \mathrm{~B}$ \\
\hline & Hydropriming & $92.5 \mathrm{~d}$ & $85.3 \mathrm{bc}$ & $87.0 \mathrm{c}$ & $79.5 \mathrm{ab}$ & $86.1 \mathrm{~B}$ \\
\hline & Osmopriming & $93.3 \mathrm{de}$ & $79.3 \mathrm{ab}$ & $82.8 \mathrm{bc}$ & $74.3 \mathrm{a}$ & $82.4 \mathrm{~A}$ \\
\hline & Mean & $93.2 \mathrm{C}$ & $86.8 \mathrm{~B}$ & $85.1 \mathrm{~B}$ & $76.2 \mathrm{~A}$ & \\
\hline \multirow{4}{*}{$\begin{array}{l}\text { Germination } \\
\text { at } 1^{\text {st }} \text { count }\end{array}$} & Control & $60.3 \mathrm{e}-\mathrm{h}$ & $42.3 \mathrm{bc}$ & $53.0 \mathrm{de}$ & $35.8 \mathrm{ab}$ & $47.8 \mathrm{~A}$ \\
\hline & Hydropriming & $66.3 \mathrm{gh}$ & $46.3 \mathrm{~cd}$ & $58.0 \mathrm{e}-\mathrm{g}$ & $29.8 \mathrm{a}$ & $50.1 \mathrm{~A}$ \\
\hline & Osmopriming & $67.8 \mathrm{~h}$ & $61.0 \mathrm{e}-\mathrm{h}$ & $63.0 \mathrm{f}-\mathrm{h}$ & $54.5 \mathrm{~d}-\mathrm{f}$ & $61.1 \mathrm{~B}$ \\
\hline & Mean & $64.8 \mathrm{D}$ & $49.8 \mathrm{~B}$ & $58.0 \mathrm{C}$ & $40.0 \mathrm{~A}$ & \\
\hline \multirow{4}{*}{$\begin{array}{l}\text { Germination } \\
\text { at } 2^{\text {nd }} \text { count }\end{array}$} & Control & $88.0 \mathrm{e}$ & $82.3 \mathrm{de}$ & $59.8 \mathrm{c}$ & $45.8 \mathrm{~b}$ & $68.9 \mathrm{~B}$ \\
\hline & Hydropriming & $84.3 \mathrm{de}$ & $47.8 \mathrm{~b}$ & $67.5 \mathrm{c}$ & $34.0 \mathrm{a}$ & $58.4 \mathrm{~A}$ \\
\hline & Osmopriming & $80.0 \mathrm{~d}$ & $63.8 \mathrm{c}$ & $67.0 \mathrm{c}$ & $58.5 \mathrm{c}$ & $67.3 \mathrm{~B}$ \\
\hline & Mean & $84.1 \mathrm{C}$ & $64.6 \mathrm{~B}$ & $64.8 \mathrm{~B}$ & $45.9 \mathrm{~A}$ & \\
\hline \multirow{4}{*}{$\begin{array}{l}\text { Abnormal diseased } \\
\text { seedlings }\end{array}$} & Control & $6.5 \mathrm{~b}$ & $10.5 \mathrm{bc}$ & $24.8 \mathrm{de}$ & 32.3 ef & $18.5 \mathrm{~B}$ \\
\hline & Hydropriming & $2.5 \mathrm{a}$ & $38.5 \mathrm{f}$ & $16.8 \mathrm{~cd}$ & $41.5 \mathrm{f}$ & $24.8 \mathrm{C}$ \\
\hline & Osmopriming & $0.8 \mathrm{a}$ & $14.5 \mathrm{c}$ & $13.8 \mathrm{c}$ & $14.8 \mathrm{c}$ & $10.9 \mathrm{~A}$ \\
\hline & Mean & $3.3 \mathrm{~A}$ & $21.2 \mathrm{~B}$ & $18.4 \mathrm{~B}$ & $29.5 \mathrm{C}$ & \\
\hline
\end{tabular}

*Values marked with the same letter, for each parameter separately, do not differ significantly at $\mathrm{p}=0.05$, according to Duncan's test

Table 2. The effect of hydro- and osmopriming on zinnia seed vigour (h)

\begin{tabular}{llllllc}
\hline Item & Treatment & Jowita & Kirke & Orys & Mix & Mean \\
\hline & Control & $32.3 \mathrm{bc}^{*}$ & $28.7 \mathrm{~b}$ & $27.1 \mathrm{~b}$ & $38.6 \mathrm{c}$ & $31.7 \mathrm{C}$ \\
Time to $10 \%$ & Hydropriming & $25.2 \mathrm{ab}$ & $29.5 \mathrm{~b}$ & $19.3 \mathrm{a}$ & $34.2 \mathrm{bc}$ & $27.1 \mathrm{~B}$ \\
germination $\left(\mathrm{T}_{10}\right)$ & Osmopriming & $19.0 \mathrm{a}$ & $19.6 \mathrm{a}$ & $19.6 \mathrm{a}$ & $20.1 \mathrm{a}$ & $19.6 \mathrm{~A}$ \\
& Mean & $25.5 \mathrm{AB}$ & $25.9 \mathrm{AB}$ & $22.0 \mathrm{~A}$ & $30.9 \mathrm{~B}$ & \\
\hline \multirow{3}{*}{$\begin{array}{l}\text { Mean germination } \\
\text { time }\end{array}$} & Control & $38.5 \mathrm{~cd}$ & $39.1 \mathrm{~d}$ & $40.1 \mathrm{~d}$ & $46.0 \mathrm{e}$ & $40.9 \mathrm{C}$ \\
& Hydropriming & $39.9 \mathrm{~d}$ & $34.1 \mathrm{c}$ & $23.7 \mathrm{~b}$ & $41.8 \mathrm{de}$ & $34.9 \mathrm{~B}$ \\
& Osmopriming & $19.4 \mathrm{ab}$ & $18.6 \mathrm{a}$ & $19.5 \mathrm{ab}$ & $20.0 \mathrm{ab}$ & $19.4 \mathrm{~A}$ \\
\hline
\end{tabular}

*Explanations: see Table 1

'Kirke'. The total number of germinating seeds for other cultivars was not affected by the applied treatments. On average, the deterioration of this parameter was noted for osmoprimed seeds (Tab. 1). However, the mean seed germination at $1^{\text {st }}$ count was higher for osmoprimed seeds than for untreated and hydroprimed ones. Osmopriming significantly improved this parameter for 'Kirke', 'Orys' and Mix, while hydropriming did not affect it for any cultivar as compared to the control (Tab. 1). Hydropriming significantly decreased seed germination at the $2^{\text {nd }}$ count for 'Kirke' and Mix. On the other hand, osmopriming resulted in a deterioration of this parameter for 'Jowita' and 'Kirke' and an improvement for Mix (Tab. 1). On average, 'Jowita' seeds were characterised by the highest germination at the $1^{\text {st }}$ and $2^{\text {nd }}$ counts, whereas the lowest values of these parameters were observed in the case of Mix seeds (Tab. 1). The reduction of seed germination at the $2^{\text {nd }}$ count for 'Kirke' after hydropriming was connected with a significant increase in the percentage of abnormal diseased seedlings. On the other hand, the percentage of these seedlings decreased significantly for 'Jowita' after hydropriming and for 'Jowita', 'Orys' and Mix after osmopriming. Hydropriming generally deteriorated this parameter as compared to the control, while osmopriming improved it. On average, the highest percentage of abnormal diseased seedlings was observed for Mix and the lowest for 'Jowita' (Tab. 1).

In general, the values of the $T_{10}$ parameter for seeds of all samples did not differ significantly (Tab. 2). 'Orys' seeds were characterised by a lower MGT value than the other cultivars (Tab. 2). On the other hand, the highest values of both parameters 
Table 3. Enzymes activity in embryos of germinating hydro- and osmoprimed zinnia seeds

\begin{tabular}{llllllc}
\hline Item & Treatment & Jowita & Kirke & Orys & Mix & Mean \\
\hline & Control & $36.4 \mathrm{ab} *$ & $36.3 \mathrm{ab}$ & $37.7 \mathrm{ab}$ & $37.6 \mathrm{ab}$ & $37.0 \mathrm{~A}$ \\
$\alpha$-Amylase $\left(\mu \mathrm{mol}^{-1}\right.$ & Hydropriming & $46.2 \mathrm{bc}$ & $44.8 \mathrm{abc}$ & $51.5 \mathrm{c}$ & $34.2 \mathrm{a}$ & $44.2 \mathrm{~B}$ \\
maltose $\left.100 \mathrm{mg} \mathrm{h}^{-1}\right)$ & Osmopriming & $54.7 \mathrm{c}$ & $50.5 \mathrm{c}$ & $49.2 \mathrm{c}$ & $45.2 \mathrm{bc}$ & $49.9 \mathrm{C}$ \\
& Mean & $45.8 \mathrm{~B}$ & $43.8 \mathrm{AB}$ & $46.1 \mathrm{~B}$ & $38.0 \mathrm{~A}$ & \\
\hline & Control & $0.52 \mathrm{~g}$ & $0.35 \mathrm{bc}$ & $0.41 \mathrm{de}$ & $0.42 \mathrm{e}$ & $0.42 \mathrm{C}$ \\
Lipases $\left(\Delta \mathrm{A} 100 \mathrm{mg}^{-1}\right.$ & Hydropriming & $0.46 \mathrm{f}$ & $0.34 \mathrm{~b}$ & $0.38 \mathrm{~cd}$ & $0.36 \mathrm{bc}$ & $0.38 \mathrm{~B}$ \\
acetone powder h $\left.\mathrm{h}^{-1}\right)$ & Osmopriming & $0.40 \mathrm{de}$ & $0.20 \mathrm{a}$ & $0.41 \mathrm{de}$ & $0.33 \mathrm{~b}$ & $0.34 \mathrm{~A}$ \\
& Mean & $0.46 \mathrm{D}$ & $0.30 \mathrm{~A}$ & $0.40 \mathrm{C}$ & $0.37 \mathrm{~B}$ & \\
\hline
\end{tabular}

*Explanations: see Table 1

were found for Mix seeds. On average, both applied treatments improved the vigour of zinnia seeds, but osmopriming did so to a larger extent than hydropriming. After osmopriming there were not significant differences in the values of $\mathrm{T}_{10}$ and MGT between the tested cultivars, while hydropriming improved $\mathrm{T}_{10}$ only for 'Orys' and MGT for 'Kirke' and 'Orys' (Tab. 2).

The enzyme activity depended on the cultivar and the method of seed priming applied (Tab. 3). On average, an increase in $\alpha$-amylase activity was found in osmo- and hydroprimed seeds. However, hydropriming increased the activity of this enzyme only in 'Orys' seeds, while osmopriming increased it in 'Jowita', 'Kirke' and 'Orys' seeds (Tab. 3). The applied treatments did not affect $\beta$-glucosidase and exopeptidase activity in the seeds of the tested cultivars. The observed values ranged from 4.00-5.54 $\mu \mathrm{mol} p$-nitrophenol $\mathrm{mg}^{-1} \mathrm{~h}^{-1}$ and 0.36-0.49 $\triangle \mathrm{A} 100 \mathrm{mg}^{-1} \mathrm{~h}^{-1}$ for $\beta$-glucosidase and exopeptidase activity, respectively (data not shown). On the other hand, a significant decrease in lipase activity in hydroprimed and osmoprimed 'Jowita' and Mix seeds as well as in osmoprimed 'Kirke' seeds was found. However, none of the treatments affected the activity of these enzymes in 'Orys' seeds. Generally, the activity of lipases in osmoprimed seeds was lower than in hydroprimed seeds (Tab. 3).

\section{DISCUSSION}

In the present experiment, the seeds of the tested cultivars differed in their response to priming. McDonald (2000) reported, on the basis of many findings, that initial seed quality may significantly influence priming success. Moreover, individual species and even seed lots may vary in response to various priming techniques. The results of previous experiments have shown that hydropriming as well as osmopriming significantly accelerated zinnia seed germination (Szopińska and Tylkowska 2009, Szopińska and Wojtaszek 2011, Szopińska 2011). However, in the present work, the positive effects of osmopriming were more conspicuous than those of hydropriming, although the level of seed moisture content achieved by using both priming methods was comparable, and ranged from 48.8 to $50.3 \%$ in individual samples. In 'Kirke' and Mix, a decrease in seed germination at the $2^{\text {nd }}$ count after hydropriming was associated with an increase in the percentage of abnormal diseased seedlings and dead seeds (data not shown). The deterioration of seed health after priming has been reported by many authors (Biniek 1994, Tylkowska and Biniek 1996, Nascimento and West 1998, Dorna et al. 2001, Tylkowska and Van den Bulk 2001, Dorna et al. 2005), also in relation to hydro- and osmoprimed zinnia seeds (Szopińska and Tylkowska 2009, Szopińska and Wojtaszek 2011). High humidity and incubation temperature during priming, especially hydropriming, favour the growth of a variety of microorganisms. On the other hand, the low osmotic potential of PEG solution could be a factor limiting the growth of fungi during osmopriming (Szopińska 2001). Nevertheless, a good solution may be combining zinnia seed priming with a chemical or biological treatment (Tylkowska and Biniek 1996, Dorna et al. 2001, Dorna et al. 2005, Szopińska 2011).

An increase in $\alpha$-amylase activity after priming has been found in the seeds of many species, e.g.: maize (Sung and Chang 1993, Sathish and Sundareswaran 2010), marigold (Afzal et al. 2011), milk thistle (Sedghi et al. 2010), muskmelon (Singh et al. 1999), oregano (Dehghanpour Farashah et al. 2011), rice (Lee and Kim 1999, Lee and Kim 2000, Basra et al. 2005) and sugar beet (Mukasa et al. 2003). Sedghi et al. (2010) reported that $\alpha$-amylase activity in milk thistle seeds primed in $\mathrm{GA}_{3}$ solution 
for $24 \mathrm{~h}$ was higher after five days of germination than in unprimed seeds. Singh et al. (1999) observed an increase in $\alpha$-amylase activity in muskmelon seeds primed in PEG and $\mathrm{KNO}_{3}$ solutions for three days. Mukasa et al. (2003) reported that the levels of amylase activity in primed sugar beet seeds were 1.9 to 11.5 times higher than those of the control seeds. An increase of $\alpha$-amylase activity was also found in Tagetes erecta L. and T. patula L. seeds primed in mannitol solution (Afzal et al. 2011), in hydroprimed and haloprimed T. patula seeds (Mukhtar et al. 2013) and in oregano seeds after priming in a PEG solution (Farashah et al. 2011). According to Basra et al. (2005), an increase in $\alpha$-amylase activity in hydroprimed and haloprimed rice seeds caused an increase in soluble sugar content, resulting in faster and more uniform plant emergence. This phenomenon was also observed in our research in primed zinnia seeds, especially after osmopriming. The lowest activity of this enzyme was detected in Mix seeds, which showed the lowest germination at the $1^{\text {st }}$ and $2^{\text {nd }}$ counts and the highest values of $\mathrm{T}_{10}$ and MGT parameters. Galani et al. (2011) and Lee and Kim (2000) observed a positive correlation between $\alpha$-amylase activity and germination percentage and the germination rate of rice seeds. In rice seeds of reduced viability and vigour, amylase activity has been shown to be lower than in seeds characterised with high germination and vigour (Nandi et al. 1995, Galani et al. 2011). Khan et al. (2013) reported that in recent harvest pea seeds, $\alpha$ - and $\beta$-amylase activity was higher compared to stored seeds. The storage period significantly affected the activity of these enzymes and a decreasing trend was observed as the storage period was prolonged and seed vigour deteriorated. In the present experiment, the untreated seeds of all of the cultivars showed the same level of $\alpha$-amylase activity despite the fact that they varied in seed germination and vigour. Nevertheless, the values of the $T_{10}$ parameter and MGT in all cultivars decreased after osmopriming and did not differ significantly, while the $\alpha$-amylase activity increased and also reached the same level. The improvement of seed vigour associated with an increase of $\alpha$-amylase activity after hydropriming was observed only in one of the tested cultivars (Orys). These results show that $\alpha$-amylase activity may be a good physiological marker in the case of osmopriming zinnia seeds but it's not fully useful as a marker of hydropriming.

In the present experiment, we did not find differences in $\beta$-glucosidase and exopeptidase activity in unprimed and primed zinnia seeds. However, Akiyama et al. (1998) observed that the activity of $\beta$-glucosidase increased more than eight-fold within five days of rice seed germination. The authors suggested that the enzyme is probably involved not only in hydrolysis but also in the modification of oligosaccharides in the cell walls of germinating rice seeds. On the other hand, Mukasa et al. (2003) reported that there was little change in $\beta$-glucosidase activity in sugar beet seeds after priming. The different priming protocols and specific seed physiology of individual species might be reasons for these varying results. Yoshiara et al. (2012) found the highest level of $\beta$-glucosidase activity in soybean seedlings only after $144 \mathrm{~h}$ of germination. Simos et al. (1994) observed that the $\beta$-glucosidase of barley seeds did not increase during germination, even in the presence of exogenously added gibberellic acid. However, the germination process affected the physical properties of $\beta$-glucosidase in terms of charge and apparent molecular weight. According to Gallardo et al. (2002), $\beta$-glucosidase is activated in the final stage of germination and plays a part in loosening the cell walls of the embryo, which allows cell elongation and root growth.

Isola and Franzoni (1996) found that initially high aminopeptidase activity in resting peanut seeds continuously declined after imbibition. The authors assumed that these enzymes may be involved in protein turnover as well as in the activation of certain apoenzymes. Kirmizi and Güleryüz (2006) observed that at the beginning of broad bean germination the activity of exopeptidase in cotyledons was higher than after five days of germination. Similarly, Politycka and Gmerek (2008) found the highest activity of this enzyme in cucumber and pea seeds after $24 \mathrm{~h}$ of germination and the lowest after $72 \mathrm{~h}$. This correlation was not observed during the germination of zinnia seeds. $\beta$-glucosidase and aminopeptidase are most likely activated in further stages of seed germination in this species.

In the present work, a higher level of lipase activity on average was found in untreated zinnia seeds than in hydro- and osmoprimed ones. In cucumber seeds, the highest level of lipase activity was observed after $24 \mathrm{~h}$ of germination and after 48 and $72 \mathrm{~h}$ this activity decreased systematically (Politycka and Gmerek 2008). Most likely, the lipolytic activity in primed zinnia seeds took place earlier than in unprimed seeds. Kubala et al. (2015) identified several genes encoding enzymes 
playing a role in lipid catabolism in oilseed rape seeds and found that some of them were strongly up-regulated already during osmopriming. During germination, triacylglycerols stored in oil bodies are quickly utilized in energy production for the synthesis of the structural compounds required for the growth of the embryo (Barros et al. 2010). The free fatty acids, products of triacylglycerols hydrolysis, are transported to peroxisome, where $\beta$-oxidation is initiated. The acetyl-CoA produced by $\beta$-oxidation enters the glyoxylate cycle and takes a part in glyconeogenesis to produce sugars used by the embryo as an energy source during germination (Quettier and Eastmond 2009).

\section{CONCLUSIONS}

1. The obtained results demonstrate that, regardless of the initial quality of the treated seeds, osmopriming is a more effective method of improving the germination and vigour of zinnia seeds than hydropriming.

2. Among the assayed enzymes, only the activity of $\alpha$-amylase may be potentially useful for the seed industry as physiological marker of zinnia seed vigour and the effectiveness of osmopriming.

\section{FUNDING}

The Poznań University of Life Sciences, Department of Plant Pathology, Seed Science and Technology - funding to maintain research potential (508.630.01.0).

\section{AUTHOR CONTRIBUTIONS}

Both authors (D.S. and B.P.) equally contributed to designing the experiments, performing analytical measurements and manuscript writing. D.S. performed the statistical analysis.

\section{CONFLICT OF INTEREST}

Authors declare no conflict of interest.

\section{REFERENCES}

Abdala A.P., Takeda L.H., Freitas Jr. J.O., Alves K.B., 1999. Purification and partial characterization of Phaseolus vulgaris seed aminopeptidase. Braz. J. Med. Biol. Res. 32: 1489-1492.

Achakzai A.K.K., Kayani S.A., Yaqoob M., Nabi A., 2003. Effect of fertilizer and inoculation on lipase and urease activity of mature soybean $\mathrm{cv}$. Williams-82 seeds. Asian J. Plant Sci. 2: 692-695.
Afzal I., Ashraf S., QAsim M., Basra S.M.A., Shahid M., Hussain B., 2011. Mannitol priming induces biochemical changes and enhances germination capacity and seedling vigor in marigold (Tagetes spp.). Acta Hortic. 898: 25-29.

Akiyama T., Kaku H., Shibuya N., 1998. A cell wall-bound $\beta$-glucosidase from germinated rice: purification and properties. Phytochemistry 48(1): 49-54.

Barros M., Fleuri L.F., Macedo G.A., 2010. Seed lipases: sources, applications and properties a review. Braz. J. Chem. Eng. 27(1): 15-29.

Basra S.M.A., Faroog M., Tabassam R., Ahmad N., 2005. Physiological and biochemical aspects of presowing seed treatments in fine rice (Oryza sativa L.). Seed Sci. Technol. 33: 623-628.

Bernfeld P., 1955. Amylases. In: Methods in Enzymology. S.P. Colowick and N.O. Kaplan (eds), Academic Press, New York: 149-158.

BINIEK A., 1994. The influence of osmoconditioning in polyethylene glycol [PEG 6000] on the germination and emergence of carrot and parsley seeds. Acta Hortic. 371: 77-81.

Cavalcanti E.D.C., Maciel F.M., Villeneuve P., Lago R.C.A., Machado O.L.T., Freire D.M.G., 2007. Acetone powder from dormant seeds of Ricinus communis L.: lipase activity and presence of toxic and allergenic compounds. Appl. Biochem. Biotechnol. 136-140(1-12): 57-65.

Dehghanpour Farashah H., Tavakkol Afshari R., Sharifzadeh F., Chavoshinasab S., 2011. Germination improvement and $\alpha$-amylase and $\beta$-1,3glucanase activity in dormant and non-dormant seeds of oregano (Origanum vulgare). Aust. J. Crop Sci. 5(4): 421-427.

Di Girolamo G., Barbanti L., 2012. Treatment conditions and biochemical process influencing seed priming effectiveness. Ital. J. Agron. 7(e25): 178-188.

Dorna H., Tylkowska K., Wei Y.H., Marcinek R., 2005. Germination and health of onion (Allium cepa) seeds after priming combined with chemical or biological treatments. Phytopathol. Pol. 37: 69-81.

Dorna H., Tylkowska K., ZhaO X., 2001. Effects of osmopriming and Rovral on health and germination of China aster seeds. Phytopathol. Pol. 21: 35-44.

Farashah H.D., Afshari R.T., Sharifzadeh F., Chavoshinasab S., 2011. Germination improvement and $\alpha$-amylase and $\beta$-1,3-glucanase activity in dormant and non-dormant seeds of oregano (Origanum vulgare). Aust. J. Crop Sci. 5(4): 421-427.

Galani S., Aman A., QAder S.A.U., 2011. Germination potential index of Sindh rice cultivars on biochemical basis, using amylase as an indicator. Afr. J. Biotechnol. 10(80): 18334-18338.

Gallardo K., Job C., Groot S.P.C., Puype M., Demol H., Vandekerckhove J., et al., 2002. Proteomics of Arabidopsis seed germination a comparative study 
of wild-type and gibberellins-deficient seeds. Plant Physiol. 129(3): 823-837.

Isola M.C., Franzoni L., 1996. Aminopeptidase activities in peanut cotyledons. Braz. J. Plant. Physiol. 8(3): 167-173.

ISTA, 2012. International Rules for Seed Testing. International Seed Testing Association, Bassersdorf, Switzerland.

Joosen R.V., Kodde J., Willems L.A., Ligterink W., VAN DER Plas L.H., Hilhorst H.W., 2010. GERMINATOR: a software package for high-throughput scoring and curve fitting of Arabidopsis seed germination. Plant J. 62(1): 148-159.

Kaneko M., Itoh H., Ueguchi-Tanaka M., Ashikari M., MatsuoKA M., 2002. The $\alpha$-amylase induction in endosperm during rice seed germination is caused by gibberellin synthesized in epithelium. Plant Physiol. 128(4): 1264-1270.

Khan M.M., Abbas M., Awan F.S., Shahid M., Alis M., Ahmad S., 2013. Physio-biochemical and genetic changes in stored pea (Pisum sativum) seeds. Int. J. Agric. Biol. 15(5): 952-956.

KIRMIZI S., GÜLERYÜZ G., 2006. Protein mobilization and proteolytic enzyme activity during seed germination of broad bean (Vicia faba L.). Z. Naturforsch. C. 61(3-4): 222-226.

Kubala S., Garnczarska M., Wojtyla Ł., Clippe A., Kosmala A., Żmieńko A., et al., 2015. Deciphering priming-induced improvement of rapeseed (Brassica napus L.) germination through an integrated transcriptomic and proteomic approach. Plant Sci. 231: 94-113.

LeE S.S., KIM J.H., 1999. Morphological change, sugar content, and $\alpha$-amylase activity of rice seeds under various priming conditions. Hanguk Jakmul Hakhoe Chi. 44(2): 138-142.

LeE S.S., Kim J.H., 2000. Total sugars, $\alpha$-amylase activity, and germination after priming of normal and aged rice seeds. Hanguk Jakmul Hakhoe Chi. 45(2): 108-111.

McDonald M.B., 2000. Seed priming. In: Seed Technology and its Biological Basis. M. Black and J.D. Bewley (eds), Sheffield Academic Press, CRC Press, Boca Raton, USA: 287-316.

Michel B.E., Kaufman M.R., 1973. The osmotic potential of Polyethylene glycol 6000. Plant Physiol. 51: 914-916.

Mukasa Y., Takahashi H., Taguchi K., Ogata N., OKazaKi K., TANAKa M., 2003. Accumulation of soluble sugar in true seeds by priming of sugar beet seeds and effects of priming on growth and yield of drilled plants. Plant Prod. Sci. 6(1): 74-82.

Mukhtar K., Afzal I., Qasim M., Basra S.M.A., Shahid M., 2013. Does priming promote germination and early stand establishment of french marigold (Tagetes patula L.) seeds by including physiological and biochemical changes? Acta Sci. Pol., Hortorum Cultus 12(3): 13-21.
NAndi S., Das G., Sen-Mandi S., 1995. $\beta$-Amylase activity as an index for germination potential in rice. Ann. Bot. 75: 463-467.

Nascimento W.M., West S.H., 1998. Microorganism growth during muskmelon seed priming. Seed Sci. Technol. 26: 531-534.

Nicols E.J., Beckman J.M., Hadwiger L.A., 1980. Glycosidic enzyme activity in pea tissue and peaFusarium solani interactions. Plant Physiol. 66: 199204.

Politycka B., Gmerek J., 2008. Effect of ferulic and $p$-coumaric acids on the activity of hydrolytic enzymes and the growth of radicles in germinating seeds of cucumber and pea. Allelopathy J. 21(2): 227238.

Quettier A.L., EAstmond P.J., 2009. Storage oil hydrolysis during early seedling growth. Plant Physiol. Biochem. 47(6): 485-490.

Sathish S., Sundareswaran S., 2010. Biochemical evaluation of seed priming in fresh and aged seeds of maize hybrid [COH(M) 5] and its parental lines. Current Biotica 4(2): 162-170.

Sedghi M., Nemati A., Amanpour-Balaneji B., Gholipouri A., 2010. Influence of different priming materials on germination and seedling establishment of milk thistle (Silybum marianum) under salinity stress. World Appl. Sci. J. 11(5): 604-609.

Simos G., Panagiotidis C.A., Skoumbas A., Choli D., Ouzounis C., Georgatsos J.G., 1994. Barley betaglucosidase: expression during seed germination and maturation and partial amino acid sequences. Biochim. Biophys. Acta 1199(1): 52-58.

Singh G., Gill S.S., SAndhu K.K., 1999. Improved performance of muskmelon (Cucumis melo) seeds with osmoconditioning. Acta Agrobot. 52(1-2): 121126.

Sung F.J.M., Chang Y.H., 1993. Biochemical activity associated with priming of sweet corn seeds to improve vigour. Seed Sci. Technol. 21: 97-105.

SzOPIŃSKA D., 2001. Wpływ wybranych metod przedsiewnego uszlachetniania na kiełkowanie, wigor i zdrowotność nasion sałaty (Lactuca sativa L.) [Effects of selected pre-sowing quality enhancement methods on germination, vigour and health of lettuce (Lactuca sativa L.) seeds]. Ph.D. dissertation, Poznań Agricultural University, Poland.

SzopińskA D., 2011. Enhancement of zinnia seeds by osmopriming and grapefruit extract treatment. Acta Sci. Pol., Hortorum Cultus 10(2): 33-47.

SzopiŃSKA D., TYlKowsKA S., 2009. Effect of osmopriming on germination, vigour and location of fungi in Zinnia elegans seeds. Phytopathol. 54: 33-44.

Szopińska D., WoJTASzeK A., 2011. Effect of hydropriming on germination and location of fungi in Zinnia elegans Jacq. seeds. Nauka Przyr. Technol. 5(6): 1-13, 117. 
Tylkowska K., Biniek A., 1996. Fungi and germination of carrot and parsley seeds under osmoconditioning and fungicide treatment. Phytopathol. Pol. 12: 5161.

Tylkowska K., VAN DEN Bulk R.W., 2001. Effects of osmo- and hydropriming on fungal infestation levels and germination of carrot (Daucus carota L.) seeds contaminated with Alternaria spp. Seed Sci. Technol. 29: 365-375.
Worthington R., 1993. Worthington Enzyme Manual. Von Worthington Biochemical Corporation, Freehold, New Jersey, USA.

Yoshiara L.Y., Madeira T.B., Ribeiro M.L.L., Mandarino J.M.G., Carrão-Panizzi M.C., IdA E.I., 2012. $\beta$-Glucosidase activity of soybean (Glycine max) embryonic axis germinated in the presence or absence of light. J. Food Biochem. 36: 699-705.

Received October 12, 2015; accepted December 13, 2015 